\title{
The Effectiveness of Post-Workout Fitness and Sports Massage in Changing Blood Pressure, Pulse Rate, and Breathing Frequency
}

\author{
Bambang Priyonoadi \\ Faculty of Sport Sciences \\ Yogyakarta State University \\ Yogyakarta, Indonesia \\ bambang_pa@uny.ac.id \\ Rachmah Laksmi Ambardini \\ Faculty of Sport Sciences \\ Yogyakarta State University \\ Yogyakarta, Indonesia \\ Rachmah_la@uny.ac.id
}

\author{
Ali Satia Graha \\ Faculty of Sport Sciences \\ Yogyakarta State University \\ Yogyakarta, Indonesia \\ Aligraha_75@yahoo.com \\ BM. Woro Kushartanti \\ Faculty of Sport Sciences \\ Yogyakarta State University \\ Yogyakarta, Indonesia \\ wkushartanti@gmail.com
}

\begin{abstract}
-massage can reduce muscular tension, accelerate blood circulation, increase nerve conductivity, breathing frequency, pulse rate, and blood flow. Sports massage, as well as the new Post-Workout Fitness Massage methods, may also decrease blood pressure, pulse rate, and breathing frequency to aid rapid the recovery of athletes. Objective: 1. To determine the effectiveness of the methods of Post-Workout Fitness Massage and Sports Massage. Some of the effects of massage include changes in pulse rate, blood pressure and respiratory frequency, 2 . To identify the types of post-workout fitness massage and sports massage that are most effective in changing pulse rate, blood pressure, and respiratory frequency. This is a queasy Experimental research with the design of Pretest-Postest using the purposive sampling technique [1.2]. The population was 27 male students and the number of samples required was 24 with the criteria of inclusion. Preliminary data were obtained by measuring systolic blood pressure (TDS), diastolic blood pressure (TDD), pulse rate (DN), and respiratory frequency (F). The results of this study indicate that 1 . Post-workout Fitness Massage and Sports Massage can reduce the systolic blood pressure of $114.72 \mathrm{mmHg}$ and $118.13 \mathrm{mmHg}$, the diastolic blood pressure of $57.72 \mathrm{mmHg}$ and $57.91 \mathrm{mmHg}$, while the pulse rate the decreases with 81.82 times/min and 79.02 times/min, as well as at respiratory frequencies of 17.91 times/min and 19.46 times/ min. 2. Sports massage is more effective in reducing TDS, TDD, DN, FP (F> 0.05). Postworkout Fitness Massage and sports massage are effective in reducing the systolic and diastolic blood pressures, pulse rate, and respiratory frequency. Sports massage is more effective for recovery compared to the fitness massage after intense physical activity.
\end{abstract}

Keywords-post-workout fitness, sports massage, changing blood pressure, pulse rate, frequency

\section{INTRODUCTION}

The new massage method was created by Bambang Priyonoadi (Post-Workout Fitness Massage Method) about 5 years ago has been recognized in 2018 by HAKI. This massage is based on only four (4) types of manipulations namely 1) rubbing, 2) shaking, 3) hitting, and 4) stretching. The purpose of this massage is to relax specific muscles that experience tension, help facilitate blood circulation and too quick recovery. Field data shows that after being massaged, students and athletes feel refreshed, recovered from tiredness quickly, and feel more comfortable and fit.

Medical measures in the form of pulse changes, blood pressure, respiratory rate, lactic acid, and fatigue, as well as laboratory changes in hormonal functions, innervation and joint and cellular extensions tissue changes, have always been done in the form of research. Contrary to sports massage, many results on medical and laboratory research have been gotten. It has been found that massage increases muscle fulfilment and also reduces the worse conditions in cross bride couplings, upright jumps, speed and reaction time [3]. The purposes of the application of sports massage in general [4] are 1) blood circulation, especially the urge to venous blood or invasion of venous blood to the heart. The smooth circulation of blood will further facilitate the process of eliminating burns and the spread of food extracts to tissues; 2) stimulates nerves, especially

peripheral nerves to increase sensitivity to stimuli; 3 ) increase the muscle tension (tone) and muscle elasticity to enhance its work power; 4) cleanse and smoothen the skin; 5) Reduce or eliminate nerve tension and reduce pain, so the patient can fall asleep. Sports massage can cause multidirectional changes in the metabolism of selected biological compounds [5].

The post-workout fitness massage method and sports massage have similarities and also distinctive differences found during the implementation of massage. The similarities in these two massages are: 1) in terms of its purpose which is to improve blood circulation, relax muscles, remove metabolic remnants, stimulate peripheral nerves, and reduce nervous tension, 2) in terms of technique both have rubbing, hitting, and shake. 3) the 
massage targets are the same, common people and sportsmen, 4) the massage direction of both massages is towards the heart, 5) manipulation begins with the legs, 6) the average massage time is $45-60$ minutes.

A very striking difference is seen from the mainstay techniques, massaging grips, the number of manipulations, different types of manipulation, initial massage position, and direction of movement of the massaged area is intended to obtain the proper body recovery. In the postworkout fitness massage method, it involves rubbing, shaking and stretching, the grip used at the beginning of each message always begins with two hands (except the arm area. The arm area begins only with one hand). The number of manipulations applied is only 4 types (i.e. rubbing, shaking, hitting, and stalling), as for the initial position to massage with a supine position first, the massaged area of the limb region (i.e. from the soles of the feet through the back of the legs, lower limbs and upper limbs simultaneously), arm and hand areas simultaneously, abdominal and chest areas simultaneously. In this supine position, massage manipulations are administered by 1) rubbing moderately, 2) rubbing strongly, 3) jolting, 4) hitting, 5) rubbing moderately (as the end for rubbing), and 6) stretching as the end. Then proceed with the prone position massage starting from the lower limb to the upper limb simultaneously, the buttock area, and the back area. It is very different from sports massage in which the mainstay of massage is rubbing, squeezing, shaking, scouring, and punching. The grip used does not always begin with two hands. The number of manipulations applied includes 9 different types, namely 1) effleurage (rubbing), 2) petrissage (squeezing and pressing), 3) shaking, 4) friction (crushing), 5) tapering with beating, 6) hitting with hacking, 7) tapotemen or hitting with clapping) 8) Walken (a variation of rubbing), 9) vibration (vibrating).

The initial position of massage is prone and the massage begins in the limb region (i.e. the upper limbs, lower limbs, and legs), buttock, back, and other areas follow suit. Then proceed with the supine position massage that starts from the area of the legs (i.e. upper limbs, lower limbs, and legs) continues on the areas of the arm, chest, abdominal, face, and head region. Every manipulation in each massaged area always starts with effleurage petrissage - shaking - tapotement - and ends with effleurage.

Differences in the basic techniques treatment, massaging grips, a number of manipulations, types of manipulation, initial massage position, and the direction of movement of the massaged area are what makes possible the differences in the effects on changing blood pressure, pulse rate, and respiratory frequency.

This study aims at a. determining the effectiveness of the post-workout fitness massage method and sports massage in changing pulse rate, blood pressure, and respiratory frequency, b. identifying which of types of post-workout fitness massage and sports massage that are most effective in changing pulse rate, blood pressure, and respiratory frequency is.
Therefore, in order to obtain the exact evidence from field data, it is necessary to conduct research to compare the effectiveness of the post-workout fitness massage and sports massage methods seen from the non-laboratory medical measurement in the form of changes in systolic blood pressure (TDS) and diastolic blood pressure ( TDD), pulse $(\mathrm{DN})$, and respiratory frequency $(\mathrm{FP})$.

\section{METHOD}

A descriptive research method was used to elucidate the findings generated in this study. The participants of this research study include $34 \mathrm{PE}$ teachers and 60 students at special schools. A combination of direct observation and questionnaire techniques were used to obtain data. The data were then analyzed using the descriptive percentage method.

\section{RESUlt AND DisCUSSION}

\section{A. Description of Research Data}

The results of the calculation of the total mean of the data description show that both massage treatments can reduce TDS, TDD, DN, and FP. Based on the data from the total mean, it was seen that the sports massage treatment can reduce TDS, TDD, DN, and FP more than postworkout fitness massage. The data calculation is as follows:

1. The mean total of sports massage in TDS decreased by $118.13 \mathrm{mmHg}>114.72 \mathrm{mmHg}$ rather than postworkout fitness massage.

2. The mean total sports massage at TDD decreased by $57.91 \mathrm{mmHg}>57.72 \mathrm{mmHg}$ rather than postworkout fitness massage.

3. The mean total massage fitness after physical activity at DN decreases 81.82 times/min> 79.02 times/min than Sports Massage

4. Most importantly, the Mean total of FP Sports Massage decreases 19.46 times/minute < 17.91 times/min than post-workout fitness massage. TDS, TDD, DN, and FP levels of pre-test and post-test were obtained and calculated to determine the gain scores (GS). The positive value $(+)$ indicates the increasing TDS/TDD, DN, and FP levels after treatments. The negative value (-) indicates the decreasing TDS, TDD, DN, and FP levels after treatments. Statistic parameters of the data are given in Table.

The results of the second normality test for massage treatments were normally distributed $p>\alpha 0.05$. The homogeneity test results are found to be homogeneous, namely $\mathrm{p}>\alpha 0.05$.

\section{The ANALysis of ResEarch Data}

Inferential Statistics Based on the Effectiveness of Both Types of Massage on Blood Pressure, Pulse Rate, and Respiratory Frequency

Based on MANOVA statistical analysis (Multivariate Analysis of Variance) using 4 statistical models 1) Pillai's trace, 2) Wilks' lambda, 3) Hoteling's trace and 4) Roy's 
Largest Root, the result of the significant level is 0.496 meaning $\mathrm{F}>0.05$. Thus, it infers that there are significant differences in post-workout fitness massage and Sports Massage on TDS, TDD, DN, and FP.

The results of the Least Significance Difference (LSD) technique on Mean Differences between Treatment Groups of Each Dependent Variable will explain the difference between the two types of massage to the changes in decreases in TDS, TDD, DN, and FP:

\section{A. Post-workout Fitness Massage Against Sports Massage}

1. Systolic Blood Pressure

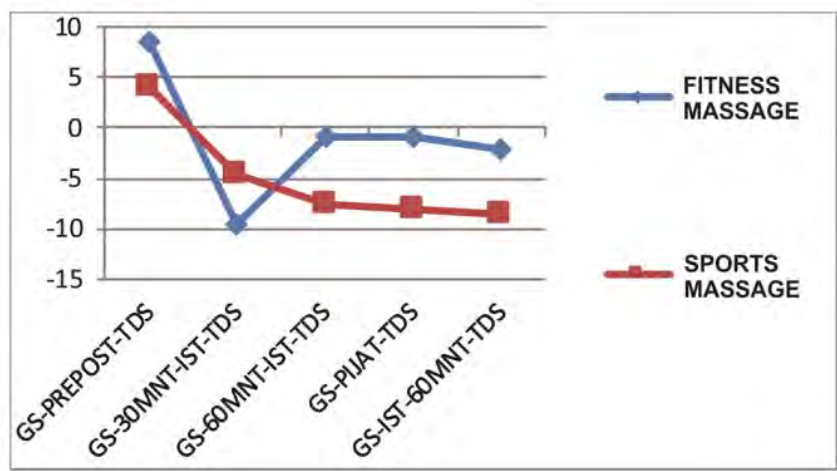

Fig. 1. Mean GS of Systolic Blood Preasure

In systolic blood pressure from the five mean GS calculation, post-workout fitness massage is obtained with sports massage greater than $\alpha 0.05(0.000>0.05)$, there is a significant difference between post-workout fitness massage and sports massage to decrease systolic blood pressure. This means that post-workout fitness massage contributes more to the decrease in systolic blood pressure in the four mean GS calculations, namely GS-pre-post-systolic, GS-ist-60min, GS-post-massage, and GS-Ist-60min compared to sports massage. It is found that the mean GS of sports massage and Post-Workout Fitness Massage is greater than $\alpha 0.05(0,000$ 5 0.05), then sports massage contributes more to the decrease in systolic blood pressure in the calculation of 1 GS that was GS-ist-30min compared to post-workout fitness massage.

\section{Diastolic Blood Pressure}

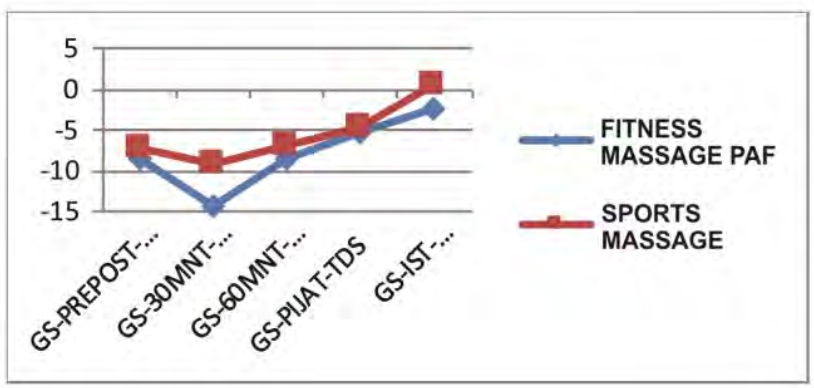

Fig. 2. Mean GS of Diastolic Blood Preasure

From the calculation of the five GS diastole pressure, there was only one sign of post-workout fitness massage with sports massage greater than $\alpha 0.05$ (0.000 50.05$)$, i.e. on GS-60 minutes. It means that post-workout fitness massage contributes a greater reduction in diastolic blood pressure in 1 calculation of mean GS, i.e. mean GS-60min Ist compared to sports massage. In contrast to post-workout fitness massage, sports massage treatment had the significance influence on diastole blood pressure which was greater than $\alpha 0.05(0.000>0.05)$ at 4 mean GS including mean GS-pre-post, mean GS-ist-30mnt, mean GS-massage and mean GS-massage-Ist-60min. This shows that sports massage has a greater contribution to the reduction of diastole blood pressure in the calculation of 4 mean GS namely mean GS-pre-post, mean GS-ist-30min, mean GSmassage, mean GS-massage-Ist-60min compared to Postworkout Fitness Massage.

\section{Pulse Rate}

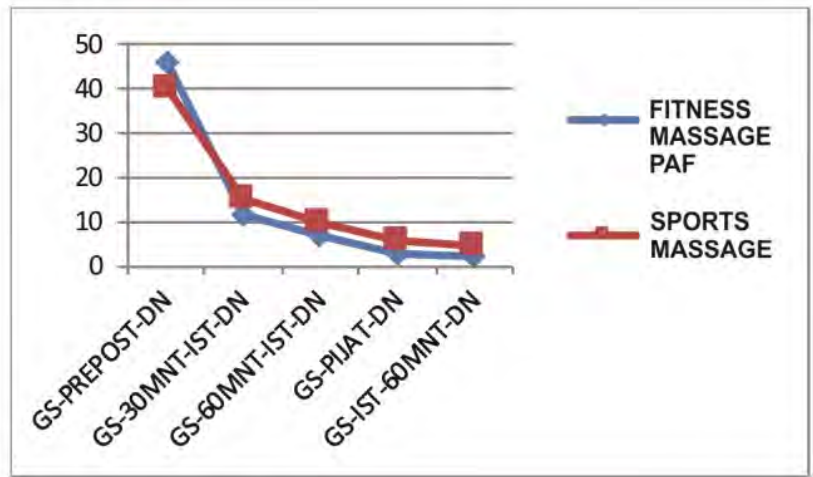

Fig. 3. Mean GS of Pulse Rate

In the pulse, there is only one fitness massage treatment after physical activity which is the mean GS-prepost which has a significance greater than $\alpha 0.05$ (0.000 5 0.05), precisely found in sports massage treatment has a significance greater than $\alpha 0,05(0,00050.05)$ at 4 mean GS. This shows sports massage contributes more to the reduction of the pulse in the calculation of the 4 mean GSs i.e. mean GS-DN-30min, mean GS-DN-60min, mean GSDN-massage, mean GS-DN-massage-Ist-60min compared with post-workout fitness massage.

\section{Respiratory Frequency}

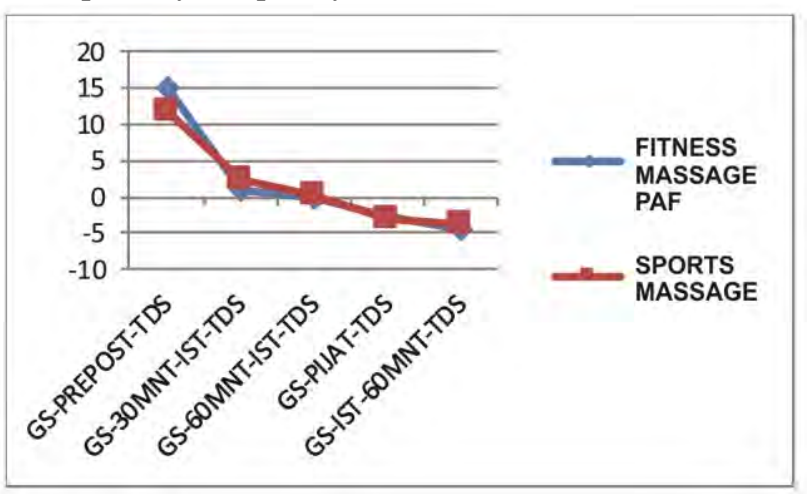

Fig. 4. Mean GS of Respiratory Frequency

The calculation of respiratory frequency in post-workout fitness massage treatment with sports massage was found to have only one difference, namely the mean GS-FP-Massage 
obtained significance greater than $\alpha 0.05(0,000>0.05)$, and only one means GS FP obtained the same reduction value, namely at GS-FP-Prepost. Different in sports massage treatment, the breathing frequency was found in a sports massage with fitness massage after the physical activity had a significance level greater than $\alpha 0.05(0,000>$ 0.05 ) at 3 mean GSs that were at mean-GS-FP-30mnt, mean- GS-FP-60min and mean GS-FP-Ist-60min. This shows that sports massage has a greater contribution to the decrease in respiratory frequency in the calculation of 3 mean GSs namely mean-GS-FP-30min, mean-GS-FP$60 \mathrm{mnt}$ and mean GS-FP-Ist-60min compared to postworkout fitness massage.

\section{B. Discussion}

Treatments of post-workout fitness massage and sports massage were determined to have effects on systolic and diastolic blood pressure, pulse and respiratory frequency. This decline occurs due to all moderate effleurage manipulations, strong effleurage, shaking, hitting, returning to moderate effleurage and effleurage manipulation, and stretching in the post-workout fitness massage, as well as effleurage manipulation, squeezing and pressing, shaking, grinding, variations of rubbing, tapering or beating with beating, tapering or hitting with hacking, tapering or hitting with clapping, and ended with effleurage in the sports massage given to the sample for 45 minutes. All treatment has the impact on the decrease in the intended dependent variable. Manipulation given in both types of massage has an effect on the reduction of systolic and diastolic blood pressure, pulse rate and respiratory frequency as shown by Ouchi [6]. Various manipulations, especially effleurage provided by post-workout fitness massage methods and sports massage, when applied with moderate pressure, slowly and smoothly, had been shown to reduce sympathetic activity and increase excitatory activity of the parasympathetic nervous system [6-8], stimulating the Valgus nerve to slow down heart rate and increase peristalsis and generate a relaxation response (Benjamin, 2005). This suggests that massage applied to medium pressure for 15 minutes causes more vagal activity [8], through effleurage and compression increases local blood flow [9], decreases systolic and diastolic blood pressure [10-11]. If the viscosity of the blood remains unchanged, an increase in blood flow will increase the shear stress in the blood vessel wall. A decrease in systolic pressure occurs due to a diagnostic cardiac catheterization [10-11]. Massage group studies showed a significant reduction in systolic blood pressure after two, three, and four weeks [12]. Cardiopulmonary effects reported by MT in the adult population include decreased blood pressure (BP) and heart rate (HR), increased peak flow and forced vital capacity, and increased comfort, pain, anxiety, and tension after heart surgery [13-16] and VCAM-1 in hypertensive individuals and women [17-19].

Sports massage is better than Post-workout Fitness Massage because the massage treatment was performed on the vital part of the organs, for example in the leg muscles, massage was carried out on the upper limbs, lower limbs, legs and soles of the feet, each of which begins with effleurage-petrissage-tapotement-shaking-ended with very powerful effleurage to give pressure and signals to the sympathetic nerves rather than post-workout fitness massage which only relies on moderate effleurage which starts from the feet and the soles of the feet go straight to the lower limbs and ends in the upper limbs followed by strong effleurageshaking-hitting-effleurage ended with stretching, thus, there is no massage on parts of the limb. Sports massage when carried out on every part of the body is always preceded by effleurage manipulation followed by manipulation of petrissage, friction, tapotement, shaking, and ends with effleurage and it is influenced by the intensity of pressure as well as the order in which massage is done, sports massage has more dominant effects on the decrease in systolic and diastolic blood pressure, pulse rate, and respiratory frequency compared to post-workout fitness massage.

\section{CONCLUSION}

Post-workout fitness massage and sports massage are effective for reducing systolic and diastolic blood pressure, pulse rate, and respiratory frequency. Sports massage is more effective for recovery than post-workout fitness massage after intense physical activity.

\section{ACKNOWLEDGMENT}

I am grateful to all the sports science students of Yogyakarta State University who have been willing to be used as samples, and the masseurs who generously assisted in administering the treatments.

\section{REFERENCES}

[1] Sugiyono, Statistika untuk penelitian. Cetakan ke-23, Penerbit: Alfabeta, Bandung. 2013.

[2] Sugiyono, Metode penelitian kombinasi (mixed methods). Penerbit: Alfabeta, Bandung. 2014.

[3] R. Arabaci, "Acute Effects of Pre-Event Lower Limb Massage on Explosive and High Speed Motor Capacities and Flexibility," Journal of Sporrts Science and Medicine. 2008, 7, 549-555.

[4] S. Findley, Sport massage. Human Kinetics, $1^{\text {st }}$ edition. Amazon Medi EU. S. arl. ISBN-13: 978-0736082600., 2-3., 23-54., 2010.

[5] A.T. Bykov, S. N. Iakimenko, L. S. Khodasevich, A.V. Poliakova, "The influence of various technologies of sports massage on biochemical parameters of the blood," Vopr Kurortol Fizioter Lech Fiz Kult. 2011Sep-Oct;(5):49-51.

[6] Y. Ouchi, T. Kanno, H. Okada et al., "Changes in cerebral blood flow under the prone condition with and without massage," Neuroscience Letters, vol. 407, no. 2, pp. 131-135, 2006. View at Publisher · View at Google Scholar · View at Scopus

[7] M. A. Diego, and T. Field "Moderate pressure massage elicits a parasympathetic nervous system response," International Journal of Neuroscience, vol. 119, no. 5, pp. 630-638, 2009. View at Publisher . View at Google Scholar · View at Scopus

[8] J. P. Delaney, K. S. Leong, A. Watkins, \& D. Brodie, "The Shortterm Effects Of Myofascial TriggerPoint Massage Therapy On Cardiac Autonomic Tone In Healthy Subjects," J Adv Nurs, 2002, 37, 364-71.

[9] P. J. Benjamin, and F. M. Tappan, Tappan's handbook of healing massage techniques ( $4^{\text {th }}$ ed.).Upper Saddle River, NJ: Pearson Prentice Hall. 2005.

[10]S. H. Cady, \& G. E. Jones, "Massage therapy as a workplace intervention for reduction of stress," Perceptual and Motor Skills, 84, 157-158. 1997. 
[11]M. E. McNamara, D. C. Burnham, C. Smith, \& D. L. Carroll, "The effects of back massage before diagnostic cardiac catheterization," Alternative Therapies in Health Medicine, 9, 50-57, 2003.

[12]Izreen Supa'at, ${ }^{1}$ Zaiton Zakaria, ${ }^{2}$ Oteh $\quad$ Maskon, ${ }^{3}$ Amilia Aminuddin, ${ }^{2}$ and Nor Anita Megat Mohd Nordin ${ }^{2}$. Effects of Swedish Massage Therapy on Blood Pressure, Heart Rate, and Inflammatory Markers in Hypertensive Women. Evidence-Based Complementary and Alternative Medicine. Volume 2013 (2013), Article ID 171852, 8 pages.

[13] J. Beeken, D. Parks, J. Cory, G. Montopoli, "The effectiveness of neuromuscular release massage therapy in five individuals with chronic obstructive lung disease," Clin Nurs Res . 1998;7(3):309-317.

[14]P. G. Anderson, S. M. Cutshall, "Massage therapy: a comfort intervention for cardiac surgery patients," Clin Nurse Spec. 2007;21(3):161-165.

[15]B. A. Bauer, S. M. Cutshall, L. J. Wentworth, D. Engen, P. K. Messner, C. M. Wood et al. "Effect of massage therapy on pain, anxiety, and tension after cardiac surgery: A randomized study," Complement Ther Clin Pract. 2010;16:70-5. [PubMed]
[16] S. M. Cutshall, L. J. Wentworth, D. Engen, T. M. Sundt, R. F. Kelly, B. A. Bauer. Effect of massage therapy on pain, anxiety, and tension in cardiac surgical patients: a pilot study. Complement Ther Clin Pract. 2010;16(2):92-95.

[17]C. M. Olney, "The effect of therapeutic back massage in hypertensive persons: a preliminary study," Biological Research for Nursing, vol. 7, no. 2, pp. 98-105, 2005. View at Publisher · View at Google Scholar . View at Scopus

[18]M. Hernandez-Reif, T. Field, J. Krasnegor, Z. Hossain, H. Theakston, and I. Burman, "High blood pressure and associated symptoms were reduced by massage therapy," Journal of Bodywork and Movement Therapies, vol. 4, no. 1, pp. 31-38, 2000. View at Publisher . View at Google Scholar · View at Scopus

[19] M. Moeini, M. Givi, Z. Ghasempour, and M. Sadeghi, "The effect of massage therapy on blood pressure of women with pre-hypertension," Iranian Journal of Nursing \& Midwifery Research, vol. 16, no. 1, pp. 61-70, 2011. View at Google Scholar 